\title{
Mediasi Intellectual Capital atas Pengaruh Digital Marketing Terhadap Kinerja Pemasaran
}

\author{
Agus Purnomo Sidi ${ }^{1}$, Ahmad Nizar Yogatama ${ }^{2}$ \\ Prodi Manajemen, STIE Asia, Indonesia
}

\author{
$\llbracket$ Corresponding Author: \\ Nama Penulis: Agus Purnomo Sidi \\ E-mail:agusps@asia.ac.id
}

\begin{abstract}
Today's world has been facing a new era that emphasizes every creative industry to overcome information technology, especially for selling and marketing needs, namely the digital era. In this era of disruptive technology, company size cannot be guaranteed, so that the creative industries processing waste and used goods can take this opportunity to penetrate domestic and international markets. The success of innovative products penetrating the global market will provide enormous benefits for the industries that show one of marketing performance, especially if it is balanced by high intellectual capital. The purpose of this study is to determine the direct and indirect effects of digital marketing on the marketing performance of creative industries processing waste and used goods through intellectual capital. The population of this research is the entire creative industries entrepreneurs processing waste and used products in Malang town whose numbers are unknown. The research sample of 150 respondents was selected through accidental-purposive-sampling technique. Quantitative primary data were collected through questionnaire surveys and analysed using path analysis. The results showed that digital marketing has direct and indirect effects on marketing performance through intellectual capital as an intervening variable which these effects are positive and significant
\end{abstract}

Keywords: intellectual capital, digital marketing, marketing performance

Abstrak: Dunia saat ini telah menghadapi era baru yang menekankan setiap industri kreatif untuk mengatasi teknologi informasi, terutama untuk kebutuhan penjualan dan pemasaran, yaitu era digital. Di era teknologi ini, ukuran perusahaan tidak dapat dijamin, sehingga industri kreatif yang mengolah limbah dan barang-barang bekas dapat mengambil kesempatan ini untuk menembus pasar domestik dan internasional. Keberhasilan produk kreatif menembus pasar global akan memberikan manfaat besar bagi industri yang menunjukkan salah satu kinerja pemasaran, terutama jika diimbangi oleh 
Agus Purnomo Sidi, Ahmad Nizar Yogatama

modal intelektual yang tinggi. Tujuan dari penelitian ini adalah untuk mengetahui efek langsung dan tidak langsung dari pemasaran digital pada kinerja pemasaran industri kreatif pengolahan limbah dan barang bekas melalui modal intelektual. Populasi penelitian ini adalah seluruh pengusaha industri kreatif yang mengolah limbah dan barang bekas di kota Malang yang jumlahnya tidak diketahui. Sampel penelitian dari 150 responden dipilih melalui teknik accidental-purposive-sampling. Data primer kuantitatif dikumpulkan melalui survei kuesioner dan dianalisis menggunakan analisis jalur. Hasil penelitian menunjukkan bahwa pemasaran digital memiliki efek langsung dan tidak langsung pada kinerja pemasaran melalui modal intelektual sebagai variabel intervening mempunyai efek positif dan signifikan.

Keywords: intellectual capital, pemasaran digital, kinerja pemasaran

\section{Cara mencitasi:}

Sidi, A.P., Yogatama, A.N. (2019). Mediasi Intellectual Capital atas Pengaruh Digital Marketing Terhadap Kinerja Pemasaran. Iqtishoduna. Vol. 15 (2): pp. 129-152

\section{Pendahuluan}

Era industri 4.0 yang juga disebut sebagai era digital telah dimulai sejak tahun 2011, di mana pada era disruptive technology ini, menurut Hassim (2016), ukuran industri tidak menjadi jaminan, justru kelincahan industri yang menjadi kunci utama dalam segala proses operasional. R evolusi industri 4.0 menjadi penggerak perekonomian dunia, bahkan, OECD (Organization for Economic Cooperation and Development) menyatakan bahwa inovasi di bidang teknologi digital diklaim mampu membawa banyak negara menuju kemakmuran yang berkesinambungan. Konektivitas yang terjalin juga menjadikan para pelaku industri kreatif terhubung dengan akses-akses modal dan pasar baru, juga membawa pada peluang bisnis-bisnis baru yang lebih menjanjikan kemakmuran (Kurniawan, 2017).

Pendekatan pemasaran baru yaitu digital marketing, dapat membantu pemasar dalam mengantisipasi serta mengelola dampak dari disruptive technology, khususnya bagi industri-industri pengolah limbah dan barang bekas yang memiliki pangsa pasar spesifik. Industri-industri kreatif jenis ini memang telah menjadi salah satu solusi masalah lingkungan dan kesehatan di kota Malang, namun tidak semua industri berhasil meraup untung besar atas usaha kreatif yang telah dilakukan. Pemanfaatan bekas CD dan bekas botol sebagai hiasan dan wadah (Ronaldo, 2017), pemanfaatan bekas bungkus minuman seduh menjadi tas, pemanfaatan koran dan buku bekas menjadi tempat tisu unik, dan tempat pensil, pemanfaatan palet kayu menjadi berbagai macam furniture unik, pemanfaatan kain perca menjadi dompet, tas, sarung

130| IQTISHODUNA Vol. 15 No. 2 Tahun 2019

http://ejournal.uin-malang.ac.id/index.php/ekonomi 
Mediasi Intellectual Capital...... bantal, bed-cover (Pasha, 2018) tidak mudah dilakukan, membutuhkan kreativitas tinggi, kesabaran dan keuletan agar produk yang dihasilkan tidak hanya memiliki nilai manfaat, namun juga memiliki estetika dan nilai ekonomi yang tinggi. Namun, pemasaran yang dilakukan dengan cara tradisional selama ini kurang memberikan hasil. Digital marketing adalah harapan bagi para pelaku industri saat ini.

Penelitian Leisander \& Dharmayanti (2017) menunjukkan bahwa digital marketing berpengaruh secara langsung terhadap kinerja industri. Sementara Anjaningrum \& Sidi (2018) menunjukkan bahwa kinerja industri mencakup 5 dimensi yaitu pertumbuhan volume penjualan, pertumbuhan modal, pertumbuhan tenaga kerja, pertumbuhan pasar, dan pertumbuhan laba. Di sisi lain, Mahardika (2007) menyatakan bahwa pertumbuhan volume penjualan, pertumbuhan pelanggan, dan pertumbuhan pendapatan merupakan indikator-indikator yang mengukur kinerja pemasaran. Ini menunjukkan bahwa digital marketing berpengaruh terhadap kinerja pemasaran.

Penelitian Leisander \& Dharmayanti (2017) juga mengungkap bahwa intellectual capital mampu memediasi pengaruh digital marketing terhadap kinerja industri. Artinya, adanya digital marketing dapat meningkatkan intellectual capital para pelaku industri yang berupa berbagai sumber daya pengetahuan karyawan, pelanggan, proses atau teknologi yang bermanfaat dalam proses penciptaan nilai bagi industri (Bukh et al., 2005). Adanya intellectual capital yang tinggi maka kinerja pemasaran yang diharapkan akan tercapai.

Oleh karena itu, penelitian ini bertujuan untuk mengetahui pengaruh langsung maupun tidak langsung digital marketing terhadap kinerja pemasaran industry-industri kreatif pengolah limbah dan barang bekas di kota Malang melalui intellectual capital sebagai variabel intervening.

\section{Kajian Pustaka \\ Industri Kreatif}

Industri kreatif, menurut Simatupang (2008) merupakan industri yang mengandalkan kreativitas, keahlian, talenta, dan ketrampilan, di mana ketiga faktor tersebut merupakan elemen dasar setiap individu. Sehingga unsur utama industri kreatif adalah kreativitas, keahlian, talenta dan ketrampilan yang berpotensi untuk meningkatkan kesejahteraan melalui penawaran kreasi intelektual. Departemen Perdagangan RI (2008) mendefinisikan sebagai industri yang berasal dari pemanfaatan kreativitas, ketrampilan serta bakat individu untuk menciptakan kesejahteraan dan lapangan pekerjaan dengan menghasilkan dan memberdayakan daya kreasi dan daya cipta individu. Terdapat 14 subsektor Industri Kreatif yang telah diidentifikasi oleh Departemen Perdagangan RI, antara lain: periklanan, arsitektur, pasar barang seni, kerajinan, desain, fesyen, video, film dan fotografi, permainan interaktif, 
Agus Purnomo Sidi, Ahmad Nizar Yogatama

musik, seni pertunjukan, penerbitan dan percetakan, layanan komputer dan piranti lunak, televisi dan radio, riset dan pengembangan. Sementara itu, Badan Ekonomi Kreatif (Bekraf) membagi industri kreatif menjadi 16 subsektor, antara lain: (1) Aplikasi dan pengembangan permainan, (2) arsitektur, (3) desain interior, (4) desain komunikasi visual, (5) desain produk, (6) fashion, (7) film, animasi dan video, (8) fotografi, (9) kriya, (10) kuliner, (11) musik, (12) penerbitan, (13) periklanan, (14) seni pertunjukan, (15) seni rupa, (16) televisi dan radio (Wulandari, 2017).

\section{Digital Marketing}

Sejak awal tahun 2000, era new wave technology telah mempengaruhi perekonomian dunia, di mana menurut Kotler \& Keller (2011), new wave technology adalah teknologi yang memungkinkan konektivitas dan interaktivitas antar individu dan kelompok. New wave meliputi tiga kekuatan utama, yaitu komputer dan telepon genggam yang murah, internet yang murah, dan open source. Berawal dari fenomena itulah, dalam hal pemasaran akhirnya dikenal istilah digital marketing. Digital marketing, menurut Satyo (2009), didefinisikan sebagai praktek marketing yang menggunakan saluran distribusi digital untuk mencapai konsumen dengan cara yang relevan, personal dan cost-effective. Sementara Chaffey \& Smith (2008) mendefinisikan digital marketing sebagai penggunaan teknologi untuk membantu aktivitas pemasaran yang bertujuan untuk meningkatkan pengetahuan konsumen dengan cara menyesuaikan dengan kebutuhan mereka. Definisi lain diberikan oleh Sawicky (2016) dalam Purwana et al. (2017) yang mengartikan bahwa digital marketing adalah suatu eksploitasi terhadap teknologi digital yang digunakan untuk menciptakan suatu saluran untuk mencapai resipien potensial untuk mencapai tujuan perusahaan melalui pemenuhan kebutuhan konsumen yang lebih efektif. Digital marketing didefinisikan juga sebagai kegiatan pemasaran yang menggunakan media berbasis internet (Wardhana, 2015). Adapun Kim (2011) menetapkan empat dimensi digital marketing, yaitu: (a) Interactive, (b) Incentive Program (c) Site Design dan (d) Cost.

\section{Intellectual Capital}

Intellectual capital, menurut Bukh et al. (2005), merupakan berbagai sumber daya pengetahuan yang berupa karyawan, pelanggan, proses atau teknologi yang bermanfaat dalam proses penciptaan nilai bagi perusahaan. Sementara menurut Maditimos (2011), intellectual capital adalah suatu pengetahuan yang bisa diubah menjadi profit. Intellectual capital ini tidak hanya menyangkut keterampilan dan pengetahuan dari para karyawan industri, melainkan juga infrastruktur yang dimiliki industri, relasi dengan 
para pelanggan, sistem informasi, teknologi, kemampuan berkreasi dan berinovasi. Intellectual capital, oleh IFAC (1998) dalam Ulum (2009), diklasifikasikan ke dalam tiga kategori, yaitu: (1) organizational capital yang terdiri dari infrastructure assests dan intellectual property, (2) relational capital, dan (3) human capital. Menurut Bontis et al. (2008), menyebut organizational capital sebagai structural capital yang meliputi seluruh nonhuman storehouses of knowledge dalam organisasi. Termasuk dalam hal ini adalah database, organisational charts, process manuals, strategies, routines dan segala hal yang membuat nilai perusahaan lebih besar daripada nilai materialnya. Sedangkan relational capital disebut juga dengan customer capital, yaitu pengetahuan yang melekat dalam marketing channels dan customer relationship di mana suatu organisasi mengembangkannya melalui jalannya bisnis. Sementara human capital, secara sederhana, merepresentasikan individual knowledge stock suatu organisasi yang direpresentasikan oleh karyawannya. Human capital merupakan kombinasi dari genetic inheritance, education, experience, and attitude tentang kehidupan dan bisnis.

\section{Kinerja Pemasaran}

Kinerja, menurut Dibrell (2008), adalah kemampuan suatu industry untuk menguasai pasar dan berorientasi pada tujuannya, khususnya tujuan keuangan. Sedangkan kinerja pemasaran, menurut Ferdinand (2004), adalah sebuah achievement yang dihasilkan oleh dampak dari berbagai peran yang berfungsi dalam sebuah organisasi. Sementara menurut Yudith (2005), kinerja pemasaran merupakan ukuran prestasi yang diperoleh dari proses aktivitas pemasaran secara menyeluruh dari sebuah organisasi. Pengukuran kinerja bermanfaat bagi pemakainya untuk menyediakan feedback yang membantu manajer dalam mengidentifikasi masalah dan membantu pemecahannya. Walau demikian, masalah pengukuran kinerja masih menjadi perdebatan klasik, karena sebagai sebuah konstruk, kinerja pemasaran bersifat multidimensional yang di dalamnya termuat beragam tujuan dan tipe organisasi. Adapun kinerja pemasaran menurut definisi Yuhui (2010) merupakan proses multidimensi yang mencakup tiga dimensi efektivitas, efisiensi dan kemampuan beradaptasi, keefektifan dan efisiensi kegiatan pemasaran organisasi terkait dengan tujuan yang terkait dengan pasar, seperti pendapatan, pertumbuhan, dan pangsa pasar.

Sehingga, menurut Ismawati (2008), kinerja sebaiknya diukur dengan menggunakan berbagai kriteria pengukuran sekaligus. Terdapat tiga indikator yang digunakan untuk mengukur kinerja pemasaran dalam penelitian menurut Ferdinand (2000). Pertama, volume penjualan, yaitu volume atau jumlah penjualan produk yang berhasil dicapai oleh perusahaan. Kedua, 
Agus Purnomo Sidi, Ahmad Nizar Yogatama

pertumbuhan pelanggan, yaitu tingkat pertumbuhan pelanggan yang berhasil dicapai oleh perusahaan. Ketiga, kemampuan menghasilkan laba, yaitu besarnya keuntungan penjualan produk yang berhasil diperoleh oleh perusahaan.

\section{Hubungan antara Digital Marketing, Intellectual Capital dan Kinerja Pemasaran}

Hasil penelitian Pradiani (2017) menunjukkan bahwa digital marketing mampu meningkatkan volume penjualan industri rumahan di kota Malang. Ini berarti digital marketing berpengaruh terhadap kinerja pemasaran. Di sisi lain, Leisander dan Dharmayanti (2017) berhasil mengungkap bahwa digital marketing berpengaruh secara langsung terhadap kinerja hotel bintang lima di Jawa Timur, juga berpengaruh secara tidak langsung, yaitu melalui intellectual capital dan perceived quality. Ini menunjukkan bahwa semakin tinggi digital marketing maka semakin tinggi intellectual capital, sebagaimana temuan Roblek et al. (2013) yang mengemukakan bahwa media sosial yang merupakan bagian dari digital marketing memberikan nilai lebih bagi pengetahuan, baik pengetahuan untuk konsumen maupun produsen. Semakin tinggi intellectual capital, maka semakin tinggi pula kinerja pemasaran. Sebagiamana yang dikemukakan oleh Zehri et al. (2012) dan Kalkan et al. (2014) bahwa intellectual capital berpengaruh positif dan signifikan terhadap kinerja perusahaan. Demikian juga dengan Camfield et al. (2018), membuktikan bahwa intellectual capital berdampak kuat terhadap kinerja perusahaan. Temuan ini selaras dengan hasil penelitian Banalzwaa \& Abdullah (2017) yang menyatakan bahwa intellectual capital penting untuk meningkatkan kinerja perusahaan. Obeidat et al. (2017) juga mengungkap bahwa intellectual capital berpengaruh positif dan signifikan terhadap kinerja industri. Sedangkan salah satu kinerja perusahaan dapat diekspresikan oleh kinerja pemasaran. Sebagaimana yang dinyatakan oleh Anjaningrum \& Sidi (2018) bahwa kinerja industri mencakup 5 dimensi yaitu pertumbuhan volume penjualan, pertumbuhan modal, pertumbuhan tenaga kerja, pertumbuhan pasar, dan pertumbuhan laba. Di sisi lain, Mahardika (2007) menyatakan bahwa pertumbuhan volume penjualan, pertumbuhan pelanggan, dan pertumbuhan pendapatan merupakan indikator-indikator yang mengukur kinerja pemasarn. Ini menunjukkan bahwa digital marketing berpengaruh terhadap kinerja pemasaran. Selain itu, Sepahvand dan Shahsiah (2015) juga menyatakan bahwa sumber daya terpenting dalam sebuah organisasi adalah intellectual capital. Pengalaman menunjukkan bahwa organisasi yang memanfaatkan sumber daya intelektualnya dengan lebih baik lebih berorientasi pada mekanisme pasar. Oleh karena itu, konsep intellectual capital dianggap paling penting dan banyak diterapkan untuk meningkatkan 
kinerja pemasaran.

Adapun Model Hipotesis penelitian sebagaimana yang disajikan dalam Gambar 1.

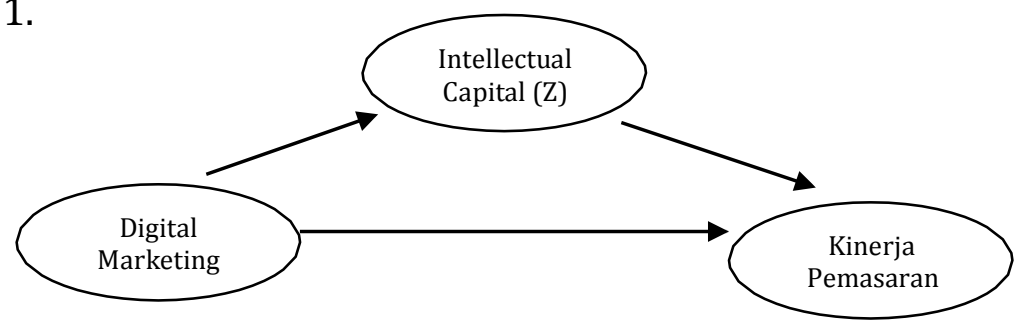

Gambar 1. Model Hipotesis Penelitian

Sedemikian hingga hipotesis penelitian ini adalah sebagai berikut:

H1: Diduga digital marketing berpengaruh secara langsung, positif dan signifikan terhadap kinerja pemasaran industri-industri kreatif pengolah limbah dan barang bekas di kota Malang.

H2: Diduga digital marketing berpengaruh secara tidak langsung, positif dan signifikan terhadap kinerja pemasaran industri-industri kreatif pengolah limbah dan barang bekas di kota Malang melalui intellectual capital sebagai variable intervening.

\section{Metodologi Penelitian}

Penelitian ini dilakukan melalui beberapa tahapan proses sesuai dengan teori Creswell (2010) yang terdiri dari: (1) Identifikasi Masalah Penelitian, (2) Review Literatur, (3) Spesifikasi Tujuan Penelitian, (4) Pengumpulan Data, (5) Analisa dan Interpretasi Data, (6) pelaporan penelitian. Populasi penelitian ini adalah seluruh industri kreatif pengolah limbah dan barang bekas di kota Malang yang jumlahnya tidak diketahui. Sampel penelitian sebanyak 150 responden dipilih melalui teknik accidental-purposive-sampling, yaitu pelaku industri yang kebetulan dijumpai oleh peneliti dan memenuhi syarat bahwa responden tersebut berdomisili di kota Malang, memiliki usaha kreatif yang berbahan dasar limbah dan barang bekas, serta bersedia memberikan segala informasi yang dibutuhkan oleh peneliti. Data primer kuantitatif dikumpulkan melalui survei kuisioner berskala likert 5 points dan dianalisis dengan menggunakan analisis jalur, di mana digital marketing merupakan variabel independent $(X)$, intellectual capital sebagai variabel intervening $(Z)$, dan kinerja pemasaran adalah variabel dependen (Y).

\section{Definisi Operasional Variabel Penelitian Digital Marketing}

Digital marketing dalam penelitian ini merupakan suatu eksploitasi terhadap teknologi digital yang digunakan untuk menciptakan suatu saluran untuk mencapai resipien potensial untuk mencapai tujuan industri-industri 
Agus Purnomo Sidi, Ahmad Nizar Yogatama

kreatif pengolah limbah dan barang bekas melalui pemenuhan kebutuhan konsumen yang lebih efektif. Adapun digital marketing diukur melalui 4 indikator menurut (Liesander \& Dharmayanti, 2017), yaitu:

1.Cost, merupakan salah satu teknik promosi yang memiliki tingkat efisiensi tinggi sehingga dapat menekan biaya dan waktu transaksi.

2.Incentive Program, adalah program-program menarik yang menjadi keunggulan dalam setiap promosi yang dilakukan. Program-program ini juga diharapkan agar dapat memberikan nilai yang lebih kepada perusahaan.

3.Site Design, merupakan tampilan menarik dalam media digital marketing yang dapat memberikan nilai positif bagi perusahaan. Site Design, merupakan tampilan menarik dalam media digital marketing yang dapat memberikan nilai positif bagi perusahaan.

4.Interactive, merupakan hubungan antara pihak perusahaan dengan konsumen yang dapat memberikan info dan dapat diterima dengan baik dan jelas.

\section{Intellectual Capital}

Intellectual capital dalam penelitian ini adalah suatu pengetahuan yang bisa diubah menjadi profit oleh industri-industri kreatif pengolah limbah dan barang bekas di kota Malang. Intellectual capital ini diukur melalui 3 indikator menurut (Liesander \& Dharmayanti, 2017) yaitu:

1.Human Capital, adalah sekumpulan aset tidak berwujud yang mencerminkan kemampuan dalam perusahaan berupa pengetahuan yang dimiliki dalam bentuk pekerja professional mereka.

2.Organizational Capital, merupakan struktur perusahaan yang mendukung usaha dari pekerja pada perusahaan tersebut untuk dapat menghasilkan kinerja intelektual yang optimal.

3.Social Capital, merupakan hubungan antara perusahaan dengan mitra kerja dan pihak eksternal perusahaan baik itu berasal dari pelanggan, pemasok, maupun hubungan antara perusahaan dengan pemerintah atau masyarakat sekitar

\section{Kinerja Pemasaran}

Kinerja pemasaran dalam penelitian ini merupakan ukuran prestasi yang diperoleh dari proses aktivitas pemasaran secara menyeluruh industriindustri kreatif pengolah limbah dan barang bekas di kota Malang. Kinerja pemasaran diukur melalui 3 indikator menurut Mahardika (2007) sebagai berikut: 
1.Pertumbuhan volume penjualan

Mediasi Intellectual Capital......

2.Pertumbuhan pelanggan

3.Pertumbuhan pendapatan.

\section{Hasil Penelitian}

Sebanyak 150 pelaku industri kreatif pengolah limbah dan barang bekas di kota Malang telah dipilih sebagai responden penelitian. Sebagian besar merupakan pengolah limbah tekstil yang berupa kain perca menjadi berbagai macam produk kreatif, pathwork, mulai dari aksesoris gantungan kunci, dompet, tas, sarung bantal, taplak meja, baju sampai bed-cover unik yang seharga mencapai Rp 3 juta per pieces. Sebagian yang lain merupakan pengolah barang bekas seperti koran dan buku bekas, botol-botol dan wadah bekas, plastik bekas, palet kayu, dan lain-lain menjadi tempat tisu, tempat pensil, kaca mata ramah lingkungan, wadah laptop, dan berbagai macam furnitur dan aksesoris lainnya. Sebagian besar pelaku usaha ini adalah perempuan. hal ini juga sesuai dengan data statistic Subdirektorat Statistik Komunikasi dan Teknologi Informasi, BPS (2016), di mana 54,96\% pengusaha ekonomi kreatif didominasi oleh pengusaha perempuan. Data yang diperoleh dari penyebaran kuisioner dalam penelitian ini diolah dan dianalisis dengan menggunakan software SPSS versi 23.

\section{Uji Instrumen Penelitian}

Uji Validitas

Supomo (2009) menyatakan bahwa suatu instrumen pengukuran dikatakan valid jika instrumen tersebut mengukur apa yang seharusnya diukur. Sementara Arikunto (2016) menjelaskan bahwa validitas merupakan suatu ukuran yang menunjukkan tingkat kevalidan atau kesahan instrument penelitian. Pengujian validitas, menurut Sugiyono (2015), dapat dilakukan dengan cara membandingkan membandingkan nilai Sig. variabel total dengan taraf nyata yang diambil, dalam penelitian ini ditentukan $\alpha=0,05$. Jika Sig. variabel total pada output Correlations lebih kecil dari 0,05 maka instrumen penelitian valid atau sah. 
Agus Purnomo Sidi, Ahmad Nizar Yogatama

Tabel 1.Correlations

\begin{tabular}{llrrr}
\hline & \multicolumn{1}{c}{$\begin{array}{c}\text { Digital } \\
\text { Marketing }\end{array}$} & $\begin{array}{c}\text { Intellectual } \\
\text { Capital }\end{array}$ & $\begin{array}{c}\text { Kinerja } \\
\text { Pemasaran }\end{array}$ & \multicolumn{2}{c}{ Total } \\
\hline $\begin{array}{l}\text { Digital } \\
\text { Marketing }\end{array}$ & Pearson Corr. & 1 & $.807^{* *}$ & $.828^{* *}$ \\
& Sig. (2-tailed) & & .000 & .000 \\
& $\mathrm{~N}$ & 150 & 150 & 150 \\
Intellectual & Peapital & $.807^{* *}$ & 1 & $.801^{* *}$ \\
& Sig. (2-tailed) & .000 & & .000 \\
Kinerja & $\mathrm{N}$ & 150 & 150 & 150 \\
Pemasaran & Pearson Corr. & $.828^{* *}$ & $.801^{* *}$ & 1 \\
& Sig. (2-tailed) & .000 & .000 & \\
Total & $\mathrm{N}$ & 150 & 150 & 150 \\
& Pearson Corr. & $.953^{* *}$ & $.925^{* *}$ & $.924^{* *}$ \\
& Sig. (2-tailed) & .000 & .000 & .000 \\
& $\mathrm{~N}$ & 150 & 150 & 150 \\
\hline
\end{tabular}

**. Correltion is significant at the 0.01 level (2-tailed).

Sumber ; Luaran SPSS ver 23, 2019

Namun sebaliknya, jika nilai Sig. variabel total pada output Correlations lebih besar dari 0,05, maka instrumen penelitian tidak valid atau tidak sah, sehingga data yang berasal dari instrumen penelitian tersebut tidak dapat dianalisis dan harus dibuang. Berdasarkan Tabel 1. Correlations di atas, diketahui bahwa nilai Sig. (2-tailed) baik variabel digital marketing, intellectual capital, maupun kinerja pemasaran sebesar 0,000 $<0,05$. Ini menunjukkan bahwa instrumen penelitian yang mengukur ketiga variabel yang diteliti valid atau sah atau dapat digunakan untuk mengukur digital marketing, intellectual capital, dan kinerja pemasaran industri-industri kreatif pengolah limbah dan barang bekas di kota Malang.

\section{Uji Reliabilitas}

Reliabilitas, menurut Supomo dan Indriantoro (2009), merujuk pada suatu pengertian bahwa suatu instrumen cukup dapat dipercaya untuk digunakan sebagai alat pengumpul data karena instrumen tersebut sudah baik. Reliabilitas juga menunjukkan konsistensi dan stabilitas dari sebuah skor atau skala pengukuran. Sementara Singarimbun (2006) menyatakan reliabilitas adalah indeks yang menunjukkan sejauh mana suatu alat pengukur dapat dipercaya atau dapat diandalkan. Makin kecil kesalahan pengukuran makin reliabel alat pengukuran. Sebaliknya makin besar kesalahan pengukuran, maka tidak reliabel alat pengukur tersebut. Untuk mengetahui reliabel atau tidaknya suatu instrumen pengambilan data dari suatu penelitian dapat dilakukan dengan melihat nilai koefisien reliabilitas (reliability 
coefficient). Nilai koefisien reliabilitas berkisar antara $0-1$, semakin nilai koefisien mendekati 1, maka instrumen yang digunakan semakin reliabel. Ukuran yang dipakai untuk menunjukkan reliabilitas adalah nilai Cronbach's alpha. Apabila nilai Cronbach's Alpha lebih besar dari 0,6, maka instrumen penelitian reliabel atau handal atau konsisten.

Tabel 2. Item-Total Statistics

\begin{tabular}{lcccc}
\hline & $\begin{array}{c}\text { Scale Mean if } \\
\text { Item Del. }\end{array}$ & $\begin{array}{c}\text { Scale Var. if } \\
\text { Item Del. }\end{array}$ & $\begin{array}{c}\text { Correc. Item- } \\
\text { Tot. Corr. }\end{array}$ & $\begin{array}{c}\text { Cronbach's } \\
\text { Alpha }\end{array}$ \\
\hline Digital Marketing & 22.11 & 11.403 & .860 & $\mathbf{. 8 8 2}$ \\
\hline $\begin{array}{l}\text { Intellectual } \\
\text { Capital }\end{array}$ & 25.69 & 15.771 & .840 & $\mathbf{. 8 6 0}$ \\
\hline $\begin{array}{l}\text { Kinerja } \\
\text { Pemasaran }\end{array}$ & 24.10 & 17.903 & .858 & $\mathbf{. 8 7 6}$ \\
\hline
\end{tabular}

Sumber: Luaran SPSS ver 23, 2019

Berdasarkan Tabel 2. Item-Total Statistics di atas, diketahui bahwa nilai Cronbach's alpha variabel digital marketing sebesar 0,882 $>0,6$. Nilai Cronbach's alpha variabel intellectual capital sebesar 0,860 $>0,6$ dan nilai Cronbach's alpha variabel kinerja pemasaran sebesar 0,876 $>0,6$. Ini menunjukkan bahwa instrumen penelitian yang mengukur digital marketing, intellectual capital, dan kinerja pemasaran industri-industri kreatif pengolah limbah dan barang bekas reliabel atau handal. Karena instrumen penelitian terbukti valid dan reliabel, maka data dapat dianalisis lebih lanjut, yaitu analisis jalur untuk mengetahui pengaruh langsung dna tidak langsung digital marketing terhadap kinerja pemasaran melalui intellectual capital sebagai variabel intervening.

Analisis Jalur (Path Analysis)

Langkah dalam analisis jalur yang pertama adalah menguji Goodness od Fit Model (Hair et al., 2009) yang menunjukkan apakah model jalur yang terbentuk dapat dipercaya atau tidak, layak atau tidak, dapat digunakan untuk memprediksi dependen variabel atau tidak. Kelayakan model ini dapat dilihat dari 2 macam uji, yaitu uji determinasi (R-Square) dan Uji F. Setelah model yang terbentuk dinyatakan layak, makan akan dibentuk model jalur yang selanjutkan dilakukan pengujian hipotesis dengan menggunakan uji $t$, analisis pengaruh langsung dan tidak langsung, serta uji sobel (Sobel-test) untuk membuktikan apakah intellectual capital memang merupakan variabel intervening yang mampu memediasi pengaruh digital marketing terhadap kinerja pemasaran atau tidak. Sobel-test ini dapat dilakukan dengan menggunakan calculator online. Berikut disajikan hasil analisis jalur penelitian ini. 
Agus Purnomo Sidi, Ahmad Nizar Yogatama

Tabel 3. Goodness of fit Model

\begin{tabular}{crrrr}
\hline Model Jalur & Nilai R & Nilai R-Square & Nilai F-hitung & \multicolumn{1}{c}{ Sig. } \\
1 &, $807^{\mathrm{a}}$ &, 652 & 276,749 &, 000 \\
2 &, $858^{\mathrm{b}}$ &, 736 & 204,662 &, 000 \\
\hline
\end{tabular}

a. Predictors: (Constant), DigitalMarketing

b. Predictors: (Constant), Intellectual Capital, DigitalMarketing

Sumber: Luaran SPSS ver 23, 2019.

Berdasarkan data dalam Tabel 3. Goodness of Fit Model, diketahui bahwa nilai R-square pada model jalur 1 sebesar 0,807. Artinya, 80,7\% intellectual capital para pelaku industri-industri kreatif pengolah limbah dan barang bekas di kota Malang dijelaskan oleh digital marketing. Hasil uji F menunjukkan bahwa nilai F-hitung-1 sebesar 276,749 > F-tabel-1 yang sebesar 3,90506 dengan Sig. sebesar 0,000 $<\alpha=0,05$ yang artinya bahwa model jalur 1 yang terbentuk memenuhi goodness of fitmodel.

Demikian juga dengan nilai R-square pada model jalur 2 sebesar 0,858. Artinya, 85,8\% kinerja pemasaran industri-industri kreatif pengolah limbah dan barang bekas di kota Malang dijelaskan oleh digital marketing dan intellectual capital. Hasil uji F menunjukkan bahwa nilai F-hitung-2 sebesar 204,662 > F-tabel-2 yang sebesar 3,057621 dengan Sig. sebesar 0,000< $\alpha=$ 0,05 yang juga berarti bahwa model jalur 2 yang terbentuk memenuhi goodness of fit model.

Berdasarkan data dalam Tabel 2. Nilai Koefisien Jalur dan t-hitung di atas, dapat dibentuk model jalur 1 yaitu $Z=1,696+0,807 \mathrm{X}+\varepsilon$ dan model jalur 2 yaitu $\mathrm{Y}=3,900+0,521 \mathrm{X}+0,380 \mathrm{Z}+\varepsilon$. Pada model jalur 1 diketahui bahwa konstanta jalur bernilai positif sebesar 1,696, sedangkan koefisien jalur dari digital marketing sebesar 0,807. Adapun nilai t-hitung digital marketing sebesar 16,636 tidak berada dalam rentang -1,976122 (-t-tabel-1) sampai 1,976122 (+t-tabel-1) dengan Sig. sebesar $0,000<\alpha=0,05$ yang menunjukkan bahwa pengaruh digital marketing terhadap intellectual capital signifikan. Artinya, tanpa adanya digital marketing sebenarnya para pelaku industri kreatif pengolah limbah dan barang bekas di kota Malang telah memiliki intellectual capital. Namun, dengan kemampuan digital marketing yang dimiliki dapat meningkatkan intellectual capital tersebut. Ini ditunjukkan oleh koefisien jalur digital marketing yang bernilai positif dan signifikan, di mana semakin tinggi kemampuan digital marketing, maka semakin tinggi pula intellectual capital. 
Tabel 4. Nilai Koefisien Jalur dan t-hitung

\begin{tabular}{|c|c|c|c|c|c|c|}
\hline \multirow[b]{2}{*}{ Model } & \multicolumn{2}{|c|}{ Unstd.Coeff. } & \multirow{2}{*}{$\begin{array}{c}\text { Std. Coeff. } \\
\text { Beta }\end{array}$} & \multirow[b]{2}{*}{ t-hitung } & \multirow[b]{2}{*}{ Sig. } & \multirow[b]{2}{*}{ Dependent Var. } \\
\hline & B & Std. Error & & & & \\
\hline 1 (Constant) & 1,696 & ,523 & & 3,241 & 001 & \\
\hline $\begin{array}{l}\text { Digital } \\
\text { Marketing }\end{array}$ & 619 & ,037 & ,807 & 16,636 & ,000 & Intellectual Capital \\
\hline 2 (Constant) & 3,900 & ,399 & & 9,774 & 000 & \\
\hline $\begin{array}{l}\text { Digital } \\
\text { Marketing }\end{array}$ & 337 & 046 & ,521 & 7,259 & 000 & Kinerja \\
\hline $\begin{array}{l}\text { Intellectual } \\
\text { Capital }\end{array}$ & 320 & 061 & 380 & 5,288 & ,000 & \\
\hline
\end{tabular}

Sumber: Output SPSS versi 23 Diolah, 2019

Pada model jalur 2 diketahui bahwa konstanta jalur bernilai positif sebesar 3,900. Artinya, tanpa adanya digital marketing dan intellectual capital sebenarnya kinerja pemasaran industri-industri kreatif pengolah limbah dan barang bekas telah menunjukkan hasil yang positif. Sedangkan koefisien jalur dari digital marketing bernilai positif sebesar 0,521 dengan nilai t-hitung sebesar 7,259 yang tidak berada dalam rentang -1,976223 (-t-tabel-2) sampai 1,976233 (+t-tabel-2) dengan Sig. sebesar 0,000 $<\alpha=0,05$. Ini menunjukkan bahwa digital marketing berpengaruh positif dan signifikan terhadap kinerja pemasaran. Sedemikian hingga hipotesis penelitian yang pertama (H1), yaitu: Diduga digital marketing berpengaruh secara langsung, positif dan signifikan terhadap kinerja pemasaran industri-industri kreatif pengolah limbah dan barang bekas di kota Malang, diterima. Semakin tinggi digital marketing maka semakin tinggi pula kinerja pemasaran.

Demikian juga dengan intellectual capital yang memiliki koefisien jalur yang juga positif sebesar 0,380 dengan nilai t-hitung sebesar 5,288 yang tidak berada dalam rentang -1,976223 (-t-tabel-2) sampai 1,976233 (+t-tabel-2) dengan Sig. sebesar $0,000<\alpha=0,05$. Ini menunjukkan bahwa intellectual capital berpengaruh positif dan signifikan terhadap kinerja pemasaran.

Tabel 5. Pengaruh Langsung dan Tidak Langsung

\begin{tabular}{lrlr}
\hline Pengaruh & $\begin{array}{c}\text { Digital Marketing ->Kinerja } \\
\text { Langsung }\end{array}$ & 0,521 & $=0,521$ \\
$\begin{array}{l}\text { Pengaruh Tidak } \\
\text { Langsung }\end{array}$ & $\begin{array}{r}\text { Digital Marketing }-> \\
\text { Intellectual Capital-> } \\
\text { KinerjaPemasaran }\end{array}$ & $0,807 * 0,380$ & $=0,307$ \\
& & Pengaruh Total & $=0.828$
\end{tabular}

Sumber: Output SPSS versi 23 Diolah, 2019.

Berdasarkan Tabel 5. Pengaruh Langsung dan Tidak Langsung di atas, diketahui bahwa pengaruh langsung digital marketing terhadap kinerja pemasaran industri-industri kreatif pengolah limbah dan barang bekas di kota Malang lebih tinggi dibandingan pengaruh tidak langsung digital marketing terhadap kinerja pemasaran melalui intellectual capital sebagai variabel 
Agus Purnomo Sidi, Ahmad Nizar Yogatama

intervening. Walau demikian, intellectual capital merupakan variabelintervening yang mampu memediasi pengaruh digital marketing terhadap kinerja pemasaran industri-industri kreatif pengolah limbah dan barang bekas di kota Malang. Hal ini dibuktikan oleh hasil Sobel-Test yang menunjukkan bahwa nilai Sobel-test-statistic sebesar 5,98997741 >1,96 (nilai Z-score- Normal pada $\alpha=0,05$ ) dengan Two-tailed probability yang sebesar $0,0<\alpha=0,05$. Sedemikian hingga hipotesis kedua (H2), yaitu: Diduga digital marketing berpengaruh secara tidak langsung, positif dan signifikan terhadap kinerja pemasaran industri-industri kreatif pengolah limbah dan barang bekas di kota Malang melalui intellectual capital sebagai variabel intervening, diterima. Semain tinggi digital marketing maka semakin tinggi intellectual capital, semakin tinggi intellectual capital semakin tinggi kinerja pemasaran.

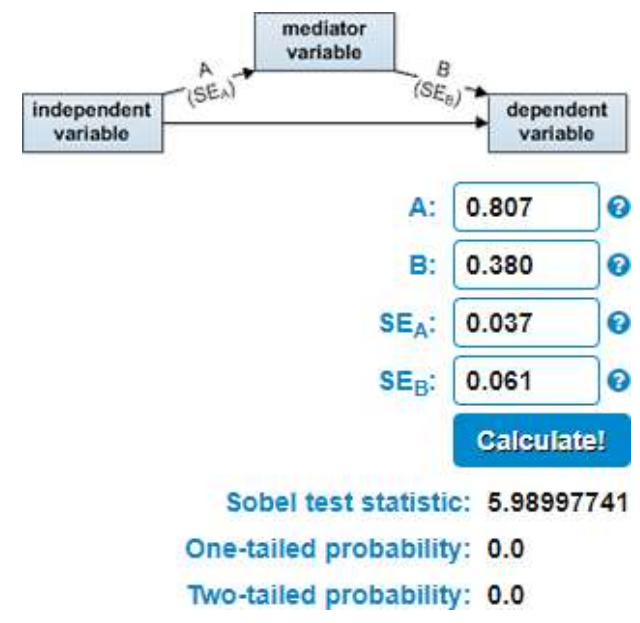

Gambar 1. Hasil Sobel-test

Sumber: https://www.danielsoper.com/statcalc/calculato

\section{Pembahasan}

\section{Digital Marketing dan Kinerja Pemasaran}

Hasil penelitian ini menunjukkan bahwa digital marketing berpengaruh secara langsung, positif dna signifikan terhadap kinerja pemasaran. Semakin tinggi digital marketing, maka semakin tinggi pula kinerja pemasaran. Sedikit saja ada peningkatan digital marketing akan berakibat pada peningkatann intellectual capital yang relatif besar. Hasil penelitian ini sejalan dengan hasil penelitian Pradiani (2017) yang menjelaskan bahwa digital marketing dapat meningkatkan volume penjualan industri makanan di kota Malang. Temuan penelitian ini juga selaras dengan hasil penelitian Leisander \& Dharmayanti (2017) yang mengungkap bahwa digital marketing berpengaruh secara langsung terhadap kinerja hotel bintang lima di Jawa Timur. Saat ini meningkatnya popularitas suatu produk adalah dampak dari industri yang mengintegrasikan teknologi ke dalam strategi pemasaran (Gibson, 2018).

142| IQTISHODUNA Vol. 15 No. 2 Tahun 2019

http://ejournal.uin-malang.ac.id/index.php/ekonomi 
Mediasi Intellectual Capital......

Temuan penelitian mendukung hasil penelitian Nuseir (2018) yang mengungkap bahwa digital marketing berdampak positif terhadap kinerja pemasaran. Selain itu, hasil penelitian ini juga selaran dengan hasil penelitian Mokhtaran\& Gilani (2016) yang menunjukkan bahwa e-marketing berpengaruh terhadap kinerja pemasaran UMKM di Teheran, di mana emarketing juga merupakan bagian dari digital marketing. Sebagaimana yang diungkap oleh Mokhtar (2015) bahwa mengadopsi internet marketing membantu usaha kecil untuk memiliki cakupan pasar yang lebih luas, mengurangi biaya pemasaran, dan meningkatkan hubungan pelanggan.

Nadya (2016) juga membuktikan bahwa perkembangan teknologi telah secara signifikan mengubah cara kerja sebuah bisnis. Di era digital ini, bisnis baru akan mudah dikenal oleh masyarakat melalui media sosial yang merupakan bagian dari digital marketing. Pemasaran produk tidak harus dilakukan secara intensif, namun konsumen yang berpindah ke pasar virally di media sosial. Bahkan, Evelina \& Handayani (2018) juga menjelaskan bahwa adanya digital influencer sangat membantu promosi produk yang berdampak pada hasil pemasaran. Menggunakan digital influencer untuk promosi memiliki kelebihan dari segi high-tech dan high-touch dibanding promosi melalui iklan. Hal ini juga dinyatakan oleh Hariyanti \& Wirapraja (2018) bahwa influencer marketing merupakan salah satu bentuk strategi melakukan digital marketing. Promosi penjualan yang tepat melalui digital marketing akan meningkatkan volume penjualan (Putri \& Safri, 2015). Nam \& Dan (2018) juga telah membuktikan dampak besar yang dihasilkan oleh social media influencer marketing terhadap volume penjualan.

Sebagaimana temuan Yasmin et al. (2015) yang mengungkap bahwa digital marketing sangat efektif dalam proses penjualan produk. Digital marketing akan sangat membantu berjalannya penerapan strategi pemasaran 8p terhadap peningkatan omzet penjualan (Saputra dkk., 2018).

Sebelumnya Widodo (2008) menyatakan bahwa perlu adanya kreativitas strategi dalam meningkatkan kinerja pemasaran. Digital marketing saat ini merupakan jawaban dari permasalahan tersebut. Saluran distribusi yang tepat penting dalam meningkatkan kinerja pemasaran. Digital marketing tidak hanya mampu menjadi sebuah media untuk menjalin konektivitas antar customer dan antara customer dengan produsen atau penjual, namun juga mampu menjadi distribution channel yang efektif. Saluran digital, menurut Stankovska et al. (2016) sangat efektif menjadi strategi marketing UKM.

Explorasi terhadap teknologi digital yang dilakukan oleh para pelaku industri kreatif pengolah limbah dan barang bekas di kota Malang dapat memberikan banyak keuntungan. Pertama, dari sisi cost, biaya yang dibutuhkan untuk pemasaran melalui teknologi digital relatif murah, sehingga dapat menekan biaya pemasaran. Biaya pemasaran tradisional sejauh ini relatif besar, bahkan sulit melakukan efisiensi. Kedua, melalui teknologi 
Agus Purnomo Sidi, Ahmad Nizar Yogatama

digital, para pelaku industri kreatif dapat berkreasi penuh dalam membuat program-program promosi yang menarik pelanggan dan memberikan nilai lebih bagi industry. Ketiga, dari sisi site design, jika site design yang digunakan sangat menarik perhatian para konsumen dapat memberikan nilai positif bagi perusahaan. Terakhir, keempat, antara produsen maupun penyalur dengan konsumen dapat berkomunikasi interaktif, sehingga semua informasi dapat diterima dengan lebih baik dan jelas. Ini penting untuk menjaga customer relationship, baik pada masa akuisisi maupun retensi.

Sayangnya masih banyak industri kreatif yang masih belum optimal memasarkan produk melalui media digital. Sebagaimana hasil penelitian Purwana dkk. (2017) yang juga menunjukkan bahwa hanya sedikit UKM yang aktif menggunakan medis sosial sebagai alat promosi dan UKM tidak memisahkan akun toko online dengan akun pribadi pemilik usaha. Sebagian besar industri yang kurang memanfaatkan digital marketing ini karena kurang memahami teknologi dan belum memiliki ketralpilan bagaimana melakukan digital marketing. Padahal Mileva \& Fauzi (2018) mengungkap bahwa sosial media marketing yang merupakan bagian dari digital marketing ini menjadi pertimbangan bagi pelanggan masa kini untuk melakukan keputusan pembelian. Kemajuan teknologi saat ini, menurut Isnaini dkk. (2017) juga telah merubah perilaku konsumen. Hal senada juga diungkap oleh Dewi \& Warmika (2017) yang menyatakan bahwa internet marketing memiliki peran penting dalam pertimbangan konsumen untuk memutusakan membeli produk atau tidak. Adede et al. (2017) sangat tegas menyatakan bahwa e-marketing yang merupakan abgian dari digital marketing ini sangat berdampak terhadap kinerja pemasaran di masa ini, jadi penting untuk tidak mengabaikannya. Sosial media bagian dari digital marketing benar-benar berdampak terhadap kinerja pemasaran suatu industri (Adegbuyi et al., 2015).

\section{Digital Marketing, Intellectual Capital, dan Kinerja Pemasaran}

Hasil penelitian ini menunjukkan bahwa digital marketing berpengaruh secara tidak langsung terhadap kinerja pemasaran melalui intellectual capital sebagai variabel intervening. Semakin tinggi digital marketing maka semakin tinggi intellectual capital, dan semakin tinggi intellectual capital maka semakin tinggi kinerja pemasaran. Intellectual capital merupakan suatu pengetahuan yang bisa diubah menjadi profit. Temuan ini sejalan dengan temuan Roblek et al. (2013) yang mengemukakan bahwa media sosial yang merupakan bagian dari digital marketing memberikan nilai lebih bagi pengetahuan, baik pengetahuan untuk konsumen maupun produsen. Jadi, semakin tinggi intellectual capital, maka semakin tinggi pula kinerja pemasaran. Hasil penelitian ini mendukung sepenuhnya temuan Leisander \& Dharmayanti (2017) dan Daniel \& Dharmayanti (2018) yang mengungkap 
bahwa digital marketing berpengaruh secara langsung maupun tidak langsung terhadap kinerja pemasaran melalui intellectual capital sebagai variabel intervening.

Sebagaimana yang dikemukakan oleh Yudhanti et al. (2011), Zehri et al. (2012), dan Kalkan et al. (2014), intellectual capital memiliki pengaruh yang positif dan signifikan terhadap kinerja perusahaan, di mana semakin tinggi intellectual capital, maka semakin tinggi pula kinerja perusahaan, khususnya kinerja pemasaran. Demikian juga dengan Camfield et al. (2018), membuktikan bahwa intellectual capital berdampak kuat terhadap kinerja perusahaan. Konsep intellectual capital ini dipopulerkan oleh Tom Stewart pada tahun 1991 ketika Fortune Magazine menerbitkan artikelnya "Brainpower: How Intellectual Capital is Becoming America's Most Important Asset" yang menggambarkan perbedaan antara nilai pasar sebuah perusahaan dengan biaya penggantian asetnya (Kalkan et al., 2014).

Temuan Dristianto \& Rodhiyah (2016) dan Banalzwaa \& Abdullah (2017) juga menyatakan hal senada bahwa intellectual capital penting untuk meningkatkan kinerja perusahaan. Obeidat et al. (2017) juga mengungkap bahwa intellectual capital berpengaruh positif dan signifikan terhadap kinerja industri. Sedangkan salah satu kinerja perusahaan dapat diekspresikan oleh kinerja pemasaran. Sebagaimana yang dinyatakan oleh Anjaningrum \& Sidi (2018) bahwa kinerja industri mencakup 5 dimensi yaitu pertumbuhan volume penjualan, pertumbuhan modal, pertumbuhan tenaga kerja, pertumbuhan pasar, dan pertumbuhan laba, di mana menurut Mahardika (2007), pertumbuhan volume penjualan, pertumbuhan pelanggan, dan pertumbuhan pendapatan merupakan indikator-indikator yang mengukur kinerja pemasaran. Ini menunjukkan bahwa digital marketing memang berpengaruh terhadap kinerja pemasaran. Selain itu, Sepahvand \& Shahsiah (2015) juga menyatakan bahwa sumber daya terpenting dalam sebuah organisasi adalah intellectual capital. Pengalaman menunjukkan bahwa sebuah industri yang mampu memanfaatkan sumber daya intelektual yang dimilikinya lebih berorientasi pada mekanisme pasar sedemikian hingga produk yang dihasilkan lebih sesuai dengan kemauan pelanggan. Hal ini secara otomatis akan meningkatkan volume penjualan yang berdampak pada peningkatan kinerja pemasaran secarakeseluruhan.

Terdapat 3 jenis intellectual capital yang perlu dioptimumkan oleh para pelaku industry rkeatif. Pertama, human capital, yaitu sekumpulan aset tidak berwujud yang mencerminkan kemampuan dalam industry kreatif berupa pengetahuan yang dimiliki dalam bentuk pekerja profesional. Industri kreatif pasti memiliki pekerja profesional dengan keahlian tinggi dan kreatif sesuai dengan bakat dan talenta masing-masing. Tidak semua orang mampu melakukan pekerjaan tersebut, terlebih melakukan berbagai kreasi untuk 
Agus Purnomo Sidi, Ahmad Nizar Yogatama

mengubah limbah dna barang bekas menjadi barang yang bermanfaat, memiliki estetika dan nilai ekonomi yang tinggi. Adanya komunikasi secara interaktif dengan para pelanggan melalui digital marketing akan lebih memudahkan para pekerja untuk membuat produk kreatif yang sesuai kemauan pelanggan, sedemikian hingga volume penjualan akan meningkat, pelanggan akan bertumbuh dan laba usaha yang diperoleh juga akan meningkat. Untuk meningkatkan kreativitas dan inovasi produk, menurut Daniel dkk. (2017) pelaku industri dapat menggunakan design thinking yang terdiri dari emphatize, define, ideate, ptototype, dan test. Dengan merepakan metode tersebut, produk industri kreatif, khususnya yang berbahan dasar limbah dan barang bekas dapat memiliki nilai jual serta bermanfaat bagi lingkungan.

Kedua, organizational capital, yaitu struktur industri kreatif yang mendukung usaha dari pekerja pada industri tersebut untuk dapat menghasilkan kinerja intelektual yang optimal. Penting bagi industri untuk memiliki struktur organisasi yang tepat, yang sesuai dengan size usaha dan jenis produk yang dihasilkan. Hasil penelitian menemukan bahwa dalam hal struktur organisasi, industri-industri kreatif di kota Malang masih belum optimal, karena sebagian pemangku jabatan adalah dari keluarga pemilik industry dan sebagian besar pekerja merupakan pekerja harian lepas. Temuan Jusoh (2015) juga menunjukkan bahwa budaya organisasi memainkan peran penting dalam mengembangkan human capital dan organizational capital, sementara kepercayaan adalah penentu utama dari semua komponen intellectual capital.

Ketiga, social capital, yaitu hubungan antara industri kreatif dengan mitra kerja dan pihak eksternal, baik itu berasal dari pelanggan, pemasok, maupun hubungan antara industri dengan pemerintah atau masyarakat sekitar. Social capital yang dimiliki oleh industry-industri kreatif yang ada di kota Malang relatif tinggi, ini juga merupakan salah satu kelebihan yang menjadikan intellectual capital secara umum relatif tinggi. Hubungan dengan mitra, tidak hanya dengan pemasok, pemerintah, dan masyarakat sekitar. Di kota Malang kolaborasi sinergis penta-helix yang terdiri dari Academic, Business, Community, Government, dan Media (ABCGM) untuk mendukung perkembangan ekonomi kreatif sudah mulai berjalan semakin baik. Jika setiap pelaku industri kreatif mau terbuka dan memanfaatkan sebaik mungkin kolaborasi tersebut, maka industri dapat meraih kinerja pemasaran yang tinggi. Intellectual capital yang didukung oleh digital marketing yang tinggi akan berdampak positif bagi kinerja pemasaran.

Jadi, potensi yang kuat untuk dikembangkan dari industri-industri kreatif pengolah limbah dan barang bekas saat ini adalah digital marketing berbiaya rendah, menggunakan incentive program yang menarik customer, 
Mediasi Intellectual Capital......

diimbangi oleh site design yang juga menarik dan melakukan komunikasi interaktif yang hangat dengan para customer. Jika hal tersebut dapat dioptimalkan, maka industri kreatif akan memiliki intellectual capital yang lebih tinggi, kafrena secara human capital, skill yang dimiliki karyawan akan diimbangi dengan pengetahuan akan harapan konsumen, social capital khususnya melalui kolaborasi sinergis penta-helix juga akan mensupport proses peningkatan kinerja pemasaran. Sedemikian hingga volume penjualan meningkat, pelanggan dan pendapatan yang diperoleh industri-industri kreatif tersebut juga bertumbuh dengan pesat.

\section{Kesimpulan}

Berdasarkan analisis data hasil penelitian, dapat ditarik beberapa kesimpulan sebagai berikut: digital marketing berpengaruh secara langsung terhadap kinerja pemasaran industri-industri kreatif pengolah limbah dan barang bekas di kota Malang; digital marketing juga berpengaruh secara tidak langsung terhadap kinerja pemasaran industri-industri kreatif pengolah limbah dan barang bekas di kota Malang melalui intellectual capital sebagai variabel intervening; komunikasi interaktif pelaku industri kreatif dengan customer melalui digital marketing menjadikan segala informasi dapat diterima dengan jelas sehingga pelaku industri dapat meningkatkan intellectual capital yang berdampak pada kinerja pemasaran.

Adapun keterbatas penelitian ini antara lain: sampel yang diambil hanya 150 orang pelaku industri kreatif yang sebagian besar adalah pengolah kain perca menjadi barang yang lebih bermanfaat, memiliki nilai estetika maupun nilai ekonomis; variabel yang dipertimbangkan dalam penelitian ini hanya 3, yaitu: variabel digital marketing sebagai variabel independent, intellectual capital sebagai variabel intervening, dan kinerja pemasaran sebagai variabel dependen; analisis hanya dilakukan pada tataran variabel, tidak menganalisis lebih mendalam sampai pada tataran indikator.

Saran yang dapat diberikan antara lain: untuk meningkatkan kinerja pemasaran sebaiknya para pelaku industri kreatif pengolah limbah dan barang bekas meningkatkan digital marketing khususnya melakukan komunikasi interaktif yang hangat dengan para konsumen, juga meningkatkan intellectual capital, khususnya human capital agar produk yang dihasilkan semakin sesuai dengan harapan konsumen dan social capital, dalam bentuk kolaborasi sinergis penta-helix; untuk mendapatkan analisis yang lebih mendalam terkait kinerja pemasaran industri-industri kreatif, diharapkan penelitian selanjutnya untuk mengambil sampel lebih dari 150 responden, mempertimbangkan variabel-variabel lain seperti orientasi pasar, orientasi kewirausahaan, dan menggunakan analisis yang lebih tinggi seperti SEM dan PLS. 
Agus Purnomo Sidi, Ahmad Nizar Yogatama

\section{Daftar Pustaka}

Adede, O. A., Francis, N. K. And Joseph, 0.0. 2017. Electronic Marketing Practices and Performance of Telecommunications Companies in Kenya. European Journal of Business and Management. Vol.9 (18). Pp.13-22.

Adegbuyi, O.A, Akinyele, F.A. and Akinyele, S.T. 2015. Effect of Social Media Marketing on Small Scale Business Performance in Ota-Metropolis, Nigeria. International Journal of Management and Social Sciences. Vol.2 (1). Pp. 1-11.

Anjaningrum, W. D., Sidi, A.P. 2018. Determinan Keunggulan Kompetitif dan Kinerja Industri Kreatif. Jurnal Ekonomi Modernisasi. Vol.14 (1).Pp. 4056.

Arikunto, S. 2016. Prosedur Penelitian Suatu Pendekatan Praktik. Jakarta: Rineka Cipta.

Banalzwaa, H. S.S and Abdullah, H.B. 2017. Mediating Effect of Intellectual Capital on The Relationships Between Information Technology for Human Resource, it for Market Information and it for Marketing Communication on Performance of Banking Sector in UAE. International Business Management. Vol.11 (2). Pp. 422-431.

Bontis, N. 2008. Intellectual Capital and Business Performance in The Portuguese Banking Industry. Maria do Rosário Cabrita. Vol. 43. Pp. 212237.

Bukh. et al. 2005. Disclosure of Information on Intellectual Capital in Danish IPO Prospectuses. Accounting, Auditing \& Accountability Journal. Vol. 18 (6). Pp 713- 732.

Camfield, C.G., Cíntia, P.G., Miguel, A.S. 2018. The impact of intellectual capital on performance in Brazilian companies. Journal of Technology Management \& Innovation. Vol.13 (2). Pp. 23-32.

Chaffey, D., \& Smith, P. R. 2008. E-Marketing Excellence: Planning and Optimizing Your Digital Marketing. (3rd edition). UK: ButterworthHeinemann.

Creswell, J.W. 2010. Research Design. Qualitative, Quantitative, and Mixed Methods Approaches. Third Edition, Sage Publication, USA.

Daniel, L., Dharmayanti, D. 2018. Pengaruh Digital Marketing terhadap Organizational Performance dengan intellectualcapital dan Perceived Quality sebagai Variabel Intervening pada Industri Hotel Bintang Empat di Jawa Timur. Jurnal Manajemen Pemasaran. Vol. 12 (1). Pp. 10-24.

Daniel, D. M., Dinda, T.I., Fenny, G., Selvy, C. 2017. Kreasi Produk Multifungsi Berbahan Kayu Bekas Peti Kemas sebagai Bidang Usaha Baru. Seminar Nasional Seni dan Desain: Membangun Tradisi Inovasi Melalui Riset Berbasis Praktik Seni dan Desain. FBS Unesa, 28 Oktober 2017. 
Mediasi Intellectual Capital......

Departemen Perdagangan RI. 2008. Rencana Pengembangan Ekonomi Kreatif Indonesia 2009-2025, Departemen Pedagangan RI, Jakarta.

Dewi, N. K.A., Warmika, I.K. 2017. Pengaruh Internet Marketing, Brand Awareness, dan Wom Communication Terhadap Keputusan Pembelian Produk Spa Bali Alus. E-Jurnal Manajemen Unud. Vol. 6 (10). Pp. 55805606.

Dibrell, C. dan Davit P.S. 2008. Fueling Innovation Trough Information Technology In SMEs. Journal of Small Business Management. Vol. 45(2). Pp. 203-218.

Dristianto, Arga, Rodhiyah. 2016. Pengaruh Intellectual Capital Terhadap Kinerja Penjualan Melalui Inovasi Produk Sebagai Variabel Intervening Pada Usaha Kecil Dan Menengah Batik Tulis Lasem Kabupaten Rembang. Jurnal Ilmu Administrasi Bisnis. Vol.5(4). Pp.1-10.

Evelina, L. W., Handayani, F. 2018. Penggunaan Digital Influencer dalam Promosi Produk (Studi Kasus Akun Instagram @bylizzieparra). Warta ISKI Vol. 01 (1). Pp. 71-82.

Ferdinand, A.T. 2000. Manajemen Pemasaran: Sebuah Pendekatan Stratejik.

Badan Penerbit Universitas Diponegoro, Semarang.

Ferdinand, A.T. 2004. Strategic Selling-In Management: Sebuah Pendekatan

Pemodelan Strategi, Research Paper Series. Universitas Diponegoro, Semarang.

Gibson, C. 2018. The Most Effective Digital Marketing Strategies \& Approaches: A Review of Literature. International Journal of Scientific and Research Publications. Vol. 8 (2). Pp.12-16.

Hair , J. F., Black , W. C., Babin, B. J., \& Anderson , R. E. 2009. Multivariate Data Analysis (Seventh ed.). United Kingdom: Pearson Education Lim-ited.

Hariyanti, N. T., Wirapraja, A. 2018. Pengaruh Influencer Marketing Sebagai Strategi Pemasaran Digital Era Moderen (Sebuah Studi Literatur). Jurnal Eksekutif. Vol. 15 (1). Pp.133-146.

Hassim, A. 2016. Revolusi Industri 4.0, retriviedfrom http://id.beritasatu.com/home/revolusi-industri-40/145390.

Ismawanti, E. 2008. Analisis Faktor-Faktor yang Mempengaruhi Kinerja Pemasaran dengan Faktor Lingkungan Sebagai Variabel Moderat (Studi Pada Industri Kerajinan Batik Di Pekalongan), Tesis. Program Studi Magister Manajemen, Program Pasca Sarjana Universitas Diponegoro, Semarang.

Isnaini, N.L., Salma, F., Rizky, T.F.H. 2017. Prosiding Seminar Nasional dan Call for Paper Ekonomi dan Bisnis (SNAPER-EBIS 2017) - Jember, 27-28 Oktober 2017 (hal 406-410)

Jusoh, K. A.R. 2015. A Multidimensional View of Intellectual Capital: The Impact on Organizational Performance. Management Decision. Vol.53(3). 
Agus Purnomo Sidi, Ahmad Nizar Yogatama

Pp. 668- 697.

Kalkan, A., Özlem, C.B., Mutlu, A. 2014. The impacts of intellectual capital, innovation and organizational strategy on firm performance. 10th International Strategic Management Conference, Procedia - Social and Behavioral Sciences. Vol.150. Pp: 700-707.

Kim, E. Y., \& Kim, Y. 2011. Predicting Online Purchase Intentions for Clothing Productsnull. European Journal of Marketing. Vol. 38(7). Pp.883-897.

Kotler, P., Keller, K.L. 2011. Manajemen Pemasaran. Edisi 13, Jilid 1, Alih Bahasa: Bob Sabran. Erlangga. Jakarta.

Kurniawan, S. 2017. Memahami Marketing 4.0 dalam konteks Ekonomi Digital, retrivied from http://marketeers.com/mengenal-marketing-4-0-dalamkonteks-ekonomi-digital/.

Liesander, I dan Dharmayanti, D. 2017. Pengaruh Digital Marketing Terhadap Organizational Performance dengan Intellectual Capital dan Perceived Quality Sebagai Variabel Intervening pada Industri Hotel Bintang Lima di Jawa Timur. Jurnal Strategi Pemasaran. Vol.2 (4). Pp. 1-13.

Mileva, Lubiana Dan Fauzi, A. Dh. 2018. Pengaruh Social Media Marketing Terhadap Keputusan Pembelian (Survei Online Pada Mahasiswa Sarjana Jurusan Ilmu Administrasi Bisnis Angkatan 2014/2015 Fakultas Ilmu Administrasi Universitas Brawijaya yang Membeli Starbucks Menggunakan Line). Jurnal Administrasi Bisnis (JAB). Vol. 58 (1). Pp. 190199.

Mokhtar, N. F. 2015. Internet Marketing Adoption by Small Business Enterprises in Malaysia. International Journal of Business and Social Science. Vol. 6 (1). Pp: 59-65.

Mokhtaran, M. and Gilani, F.H. 2016. The Effect of Using E-Marketing in SME Marketing Success. Applied mathematics in Engineering, Management and Technology. Vol.4 (3).Pp:8-14

Nadya. 2016. Peran Digital Marketing Dalam Eksistensi Bisnis Kuliner Seblak Jeletet Murni. Jurnal Riset Manajemen Dan Bisnis. Vol.1(2). Pp. 133-144.

Nam, L.G., Dan, H.T. 2018. Impact of social media Influencer marketing on consumer at Ho Chi Minh City. The International Journal of Social Sciences and Humanities Invention. Vol.5(05):4710-4714.

Nuseir, M.T. 2018. Digital Media Impact on SMEs Performance in The UAE. Academy of Entrepreneurship Journal. Vol.24(2). Pp. 1-13.

Obeidat, Bader \& Abdallah, Ayman \& Osama Aqqad, Noor \& Hakeem Oqlah M. Akhoershiedah, Abdel \& Maqableh, Mahmoud. (2017). The Effect of Intellectual Capital on Organizational Performance: The Mediating Role of Knowledge Sharing. Communications and Network. Vol.09(1). P.27. 10.4236/cn.2017.91001.

Pasha, A. R.. 2018. Raup Untung Besar dari Bisnis Daur Ulang Barang Bekas, 
Mediasi Intellectual Capital......

retrivied from https://www.cermati.com/artikel/raup-untung-besardari-bisnis-daur-ulang-barang-bekas.

Pradiani, T. 2017. Pengaruh Sistem Pemasaran Digital Marketing Terhadap Peningkatan Volume Penjualan Hasil Industri Rumahan. Jurnal Ilmiah Bisnis dan Ekonomi STIE Asia Malang. Vol. 11(2). Pp. 46-53.

Purwana, D., Rahmi., Shandy, A. 2017. Pemanfaatan Digital Marketing Bagi Usaha Mikro, Kecil, Dan Menengah (UKM) di Kelurahan Malaka Sari, Duren Sawit. Jurnal Pemberdayaan Masyarakat Madani (JPMM). Vol. 1(1). Pp.1-17.

Putri, R. S., Safri, I. 2015. Pengaruh Promosi Penjualan Dalam Meningkatkan Penjualan Mobil Mitsubishi Pada PT. Pekan Perkasa Berlian Motor Pekanbaru. Jurnal Valuta. Vol.1 (2). Pp. 298-321.

Mahardika, R. 2007. Analisis Faktor-Faktor Yang Mempengaruhi Efektivitas Penjualan Terhadap Kinerja Pemasaran (Studi Kasus Pada Tenaga Penjual Perusahaan Distributor Convenience Product di Kota Semarang), Tesis. Program Studi Magister Management, Program Pasca Sarjana, Universitas Diponegoro, Semarang.

Roblek, Vasja, Mirjana Peji Bach, Maja Meško, and Andrej Bertoncelj. (2013). The Impact of Social Media to Value Added in Knowledge-Based Industries. $\quad$ Kybernetes. $\quad$ Vol.42(4). Pp. 554-568. http://dx.doi.org/10.1108/K-01-2013-0014.

Ronaldo. 2017. 10 Kerajinan Tangan Dari Barang Bekas Ini Bisa Dijual Mahal Lho, retrivied from https://www.idntimes.com/life/diy/ronaldo3/kerajinan-tangan-dari-barang-bekas-c1c2/full.

Saputra, A. D., Rahman, N., Andhika, P.C. 2018. Penerapan Strategi Pemasaran 8p Terhadap Peningkatan Omset Penjualan Pada Warung Marso Malang. Jurnal Eksekutif. Vol. 15(1). Pp. 19-41.

Satyo, F. 2009. Intellectual Capital. Gramedia Pustaka Utama, Jakarta. Sepahvand, R \& Mousavi, S.N. \& Shahsiah, N. 2015. The Effect of Intellectual Capital on Market Orientation According to The Role of Knowledge Sharing Mediator Variable (Supervision Of Insurance Companies In Lorestan Province). IJ A B E R. Vol. 13(8). Pp. 6603-6617.

Simatupang, M. T. 2008. Industri Kreatif untuk Kesejahteraan Bangsa. ITB Bandung: Inkubator Industri dan Bisnis.

Singarimbun, Masri dan Effendi, Sofian (Editor). 2011. Metode Penelitian Survay. Jakarta: PT Pustaka LP3ES Indonesia.

Stankovska, Ivana, Saso Josimovski \& Christopher Edwards. 2016. Digital channels diminish SME barriers: the case of the UK, Economic ResearchEkonomska Istraživanja. Vol. 29(1). Pp. 217-232.

Subdirektorat Statistik Komunikasi dan Teknologi Informasi, BPS 2016. Profil Usaha/Perusahaan 16 Subsektor Ekraf Berdasarkan Sensus Ekonomi 2016 
Agus Purnomo Sidi, Ahmad Nizar Yogatama

(SE2016). Badan Pusat Statistik, Dharmaputra, Jakarta.

Sugiyono (2015). Metode Penelitian Kombinasi (Mix Methods). Bandung: Alfabeta.

Supomo, B., Indriantoro, N. 2009. Metodologi Penelitian Bisnis untuk Akuntansi dan Manajemen, Edisi Pertama. Yogyakarta : BPFE Yogyakarta.

Ulum, I. 2009. Intellectual Capital: Konsep dan Kajian Empiris. Graha Ilmu, Yogyakarta.

Wardhana, A. 2015. Strategi Digital Marketing dan Implikasinya pada Keunggulan Bersaing UKM di Indonesia, retrivied from http://www.academia.edu/17287897/STRATEGI_DIGITAL_MARKETING_DAN_ IMPLIKASINYA_PADA_KEUNGGULAN_BERSAING_UKM_DI_INDONESIA.

Widodo. 2008. Meningkatkan Kinerja Pemasaran dengan Kreativitas Strategi. Integritas - Jurnal Manajemen Bisnis. Vol. 1(2). Pp: 151-175.

Wulandari, S. 2017. Laporan PDB Ekonomi Kreatif Tahun 2014-2016. Badan Pusat Statistik. Jakarta.

Yasmin, A., Sadia, T., and Kaniz, F. 2015. Effectiveness of Digital Marketing in the Challenging Age: An Empirical Study. International Journal of Management Science and Business Administration. Volume 1(5). Pp. 6980.

Yudhanti, Ceicilia, B.H., Josepha C. S. 2011. Intellectual Capital dan Ukuran Fundamental Kinerja Keuangan Perusahaan. Jurnal Akuntansi dan Keuangan. Vol. 13(2). Pp. 57-66.

Yudith, N. F. 2005. Analisis Distribusi Selling-In untuk Meningkatkan Kinerja Pemasaran (Dalam Hubungan Antara PT. Expand Berlian Mulia dengan Outlet-Outletnya di Wilayah Jawa Tengah dan Yogyakarta). Tesis. Program Studi Magister Manajemen. Program Pasca Sarjana. Universitas Diponegoro.Semarang.

Yuhui, G. 2010. Measuring Marketing Performance: A Review and A Framework. The Marketing Review. Vol.10. Pp. 25-40. 10.1362/146934710X488924.

Zehri, C.,, Asma, A., Najla, B. 2012. How Intellectual Capital Affects A Firm's Performance? Australian Journal of Business And Management Research. Vol.2 (8). Pp: 24-31.

\section{PERNYATAAN / PENGHARGAAN}

Penulis mengucapkan terimakasih yang sebesar-besarnya atas dana penelitian yang diberikan oleh DRPM Ristekdikti melalui skema Penelitian Dosen Pemula (PDP) sehingga proses penelitian ini dapat berjalan dengan lancar. Tidak lupa penulis juga mengucapkan terimakasih kepada seluruh komunitas industri kreatif di kota Malang yang terlibat dalam proses penelitian sehingga penulis mendapatkan kemudahan dalam mencari responden penelitian. 